\title{
Polymyalgia rheumatica: an arthroscopic study of the shoulder joint
}

\author{
W. A. C. DOUGLAS, B. A. MARTIN, AND J. H. MORRIS \\ From the Rheumatology Unit and Orthopaedic Department, Princess Alexandra Hospital, Ipswich Road, \\ Brisbane, Australia
}

SUMmARY A careful selection of 19 patients fitting the classical description of polymyalgia rheumatica have been examined by arthroscopy and thoroughly screened and followed up to exclude rheumatoid arthritis and other disease processes. Synovitis of the shoulder joint has been observed through the arthroscope in 17 and synovitis of varying degrees noted histologically, 4 of whom were studied by immunofluorescence. Five patients had radioactive joint scans.

Barber $^{1}$ coined the term polymyalgia rheumatica to describe a group of cases with myalgic symptoms and constitutional effects. Since then there has been controversy as to the nature of this illness. As there is no internationally accepted definition of polymyalgia rheumatica, the condition tends to become a diagnosis of exclusion. Dixon ${ }^{2}$ described it as a protracted illness of the elderly with pain and stiffness in central muscles and joints associated with a raised blood sedimentation rate. Bird et al. ${ }^{3}$ outlined criteria for the diagnosis of this condition. Gordon et al. ${ }^{4}$ biopsied the shoulder joint under local anaesthetic in 6 patients with polymyalgia and reported the presence of a nonspecific synovitis. Henderson et al. ${ }^{5}$ described synovial fluid analysis and biopsy observations in 4 patients with polymyalgia who developed synovitis of the knee joint. Bruk ${ }^{6}$ described histological synovitis of the sternoclavicular joint in his series, while O'Duffy et al. ${ }^{7}$ in one biopsy revealed synovitis of the knee with lymphocytic infiltration. They ${ }^{7}$ reported abnormal joint scans in 24 of 25 patients in their series.

Because of the nonspecific nature of the synovial changes these findings evoked little interest, and the role of synovitis in polymyalgia rheumatica has been generally considered to be unimportant. Pain and some shoulder stiffness is rapidly relieved by intraarticular injection of $2 \%$ lignocaine, and, as the shoulder signs in polymyalgia rheumatica are those seen in arthritis of the shoulder joint, the following study was undertaken to examine the hypothesis of an underlying arthritic process.

Accepted for publication 12 July 1982.

Correspondence to Dr W. A. C. Douglas, Rheumatology Unit, Princess Alexandra Hospital, Brisbane, Australia 4102.

\section{Patients and methods}

In October 1978 the first patient in the series was arthroscoped and since that time a total of 19 patients aged between 50 and 79 , including 13 females and 6 males, have been selected and carefully followed up. The mean follow-up period is 15 months.

The patients were selected on criteria suggested by Bird et al. ${ }^{3}$ The main clinical features were: age above 50 years; onset of severe pain and stiffness within weeks or months of the consultation; pain and stiffness limited to shoulders, neck, and hips; no patient had inflammatory involvement of peripheral joints; blood sedimentation rate above $30 \mathrm{~mm} / \mathrm{h}$ (Westergren); all patients had a full blood count, blood sedimentation rate, serology for rheumatoid factor, antinuclear antibodies, and multiple biochemical analysis. Ten of the 19 patients had had creatinine phosphokinase levels checked, with normal results. $X$-rays of chest, pelvis, and shoulders were also included in the screening tests. These investigations were performed to exclude as far as possible rheumatoid disease, secondary neoplasm of bone, and other conditions masquerading as polymyalgia rheumatica. None of the patients received corticosteroids prior to these investigations either orally of intra-articularly. For details of the patients see Table 1.

Arthroscopy was performed under a general anaesthetic. The shoulder joint was entered anteriorly below the clavicle. $X$-ray guidance after experience with the first case was found to be unnecessary. The procedure was not difficult, and the shoulder joint was entered with ease. No significant morbidity followed the procedure. 
312 Douglas, Martin, Morris

Table 1 Polymyalgia rheumatica: patient data

\begin{tabular}{|c|c|c|c|c|c|c|c|}
\hline Case & $\begin{array}{l}\text { Age } \\
\text { (years) }\end{array}$ & Sex & $\begin{array}{l}\text { Date of } \\
\text { diagnosis, } \\
\text { month/year }\end{array}$ & $\begin{array}{l}\text { First ESR } \\
\text { (Westergren) } \\
\mathrm{mm} / \mathrm{h}\end{array}$ & $\begin{array}{l}\text { Arthroscopic } \\
\text { synovitis }\end{array}$ & Pain & $\begin{array}{l}\text { Current } \\
\text { follow-up }\end{array}$ \\
\hline 1 & 65 & $\mathrm{~F}$ & $10 / 78$ & 50 & $\stackrel{+}{\text { Effusion }}$ & $\begin{array}{l}\text { Shoulders, } \\
\text { hips }\end{array}$ & $\begin{array}{l}\text { Asymptomatic, } \\
\text { steroids ceased }\end{array}$ \\
\hline 2 & 73 & $\mathrm{~F}$ & $2 / 79$ & 65 & $\begin{array}{l}+ \\
\text { Effusion }\end{array}$ & $\begin{array}{l}\text { Shoulders, } \\
\text { hips }\end{array}$ & $\begin{array}{l}\text { Asymptomatic, } \\
\text { steroids ceased }\end{array}$ \\
\hline 3 & 66 & $\mathbf{M}$ & $4 / 79$ & 62 & + & $\begin{array}{l}\text { Shoulders, } \\
\text { hips, }\end{array}$ & $\begin{array}{l}\text { Asymptomtic, } \\
\text { steroids ceased }\end{array}$ \\
\hline 4 & 71 & $\mathrm{~F}$ & $10 / 79$ & 68 & + & $\begin{array}{l}\text { Shoulders, } \\
\text { hips }\end{array}$ & $\begin{array}{l}\text { Asymptomatic, } \\
\text { steroids ceased }\end{array}$ \\
\hline 5 & 70 & $\mathbf{M}$ & $1 / 80$ & 60 & + & $\begin{array}{l}\text { Shoulders, } \\
\text { hips, neck }\end{array}$ & $\begin{array}{l}\text { Asymptomatic, } \\
\text { steroids ceased }\end{array}$ \\
\hline 6 & 55 & $\mathrm{~F}$ & $2 / 80$ & 50 & - & $\begin{array}{l}\text { Shoulders, } \\
\text { hips, neck }\end{array}$ & $\begin{array}{l}\text { Asymptomatic } \\
\text { prednisone } 3 \mathrm{mg}\end{array}$ \\
\hline 7 & 68 & $\mathrm{~F}$ & $4 / 80$ & 55 & Effusion & $\begin{array}{l}\text { Shoulders, } \\
\text { hips, neck }\end{array}$ & $\begin{array}{l}\text { Asymptomatic, } \\
\text { prednisone } 4 \mathrm{mg}\end{array}$ \\
\hline 8 & 75 & $\mathrm{~F}$ & $6 / 80$ & 50 & + & $\begin{array}{l}\text { Shoulders, } \\
\text { hips }\end{array}$ & $\begin{array}{l}\text { Asymptomatic, } \\
\text { steroids ceased }\end{array}$ \\
\hline 9 & 73 & $\mathrm{~F}$ & $7 / 80$ & 63 & + & $\begin{array}{l}\text { Neck, hips, } \\
\text { shoulders }\end{array}$ & $\begin{array}{l}\text { Asymptomatic, } \\
\text { naproxen }\end{array}$ \\
\hline 10 & 79 & $\mathbf{M}$ & $1 / 81$ & 65 & + & $\begin{array}{l}\text { Shoulders, } \\
\text { hips }\end{array}$ & $\begin{array}{l}\text { Asymptomatic, } \\
\text { prednisone } 7 \mathrm{mg}\end{array}$ \\
\hline 11 & 52 & $\mathrm{~F}$ & $2 / 81$ & 46 & + & $\begin{array}{l}\text { Shoulders, } \\
\text { hips, SCJs }\end{array}$ & $\begin{array}{l}\text { Asymptomatic, } \\
\text { prednisone } 6 \mathrm{mg}\end{array}$ \\
\hline 12 & 75 & $\mathbf{M}$ & $6 / 81$ & 54 & + & Shoulders, & $\begin{array}{l}\text { Asymptomatic } \\
\text { prednisone } 8 \mathrm{mg}\end{array}$ \\
\hline 13 & 76 & $\mathrm{~F}$ & $7 / 81$ & 40 & $\stackrel{+}{\text { Effusion }}$ & $\begin{array}{l}\text { Shoulders, } \\
\text { hips }\end{array}$ & $\begin{array}{l}\text { Stiffness, } \\
\quad \text { prednisone } 7 \mathrm{mg}\end{array}$ \\
\hline 14 & 50 & $\mathrm{~F}$ & $8 / 81$ & 48 & + & $\begin{array}{l}\text { Shoulders, } \\
\text { hips }\end{array}$ & Prednisone $8 \mathrm{mg}$ \\
\hline 15 & 53 & $\mathrm{~F}$ & $12 / 81$ & 53 & + & $\begin{array}{l}\text { Shoulders, } \\
\text { neck, hips }\end{array}$ & $\begin{array}{l}\text { Prednisone } 5 \mathrm{mg} \\
\text { asymptomatic }\end{array}$ \\
\hline 16 & 65 & $\mathbf{M}$ & $12 / 81$ & 51 & + & $\begin{array}{l}\text { Shoulders, } \\
\text { hips }\end{array}$ & $\begin{array}{l}\text { Prednisone } 5 \mathrm{mg} \text {, } \\
\text { asymptomatic }\end{array}$ \\
\hline 17 & 64 & $\mathbf{M}$ & $12 / 81$ & 56 & + & $\begin{array}{l}\text { Shoulders, } \\
\text { hips }\end{array}$ & $\begin{array}{l}\text { Prednisone } 6 \mathrm{mg} \text {, } \\
\text { mild symptoms }\end{array}$ \\
\hline 18 & 65 & $\mathrm{~F}$ & $3 / 82$ & 64 & + & $\begin{array}{l}\text { Shoulders, } \\
\text { hips }\end{array}$ & $\begin{array}{l}\text { Prednisone } 5 \mathrm{mg} \text {, } \\
\text { mild symptoms }\end{array}$ \\
\hline 19 & 72 & $F$ & $3 / 82$ & 108 & + & $\begin{array}{l}\text { Shoulders, } \\
\text { hips }\end{array}$ & $\begin{array}{l}\text { Prednisone } 5 \mathrm{mg} \text {, } \\
\text { mild symptoms }\end{array}$ \\
\hline
\end{tabular}

SCJs $=$ sternoclavicular joints.

The instrument used was the Stortz $3.8 \mathrm{~mm}$ telescope with a $30^{\circ}$ angle for viewing, while the Stortz telescope $2.8 \mathrm{~mm}$ was used for biopsy purposes. Biopsies were taken either through an independent capsular penetration with biopsy forceps or through the instrument itself, though the latter procedure provided a smaller biopsy sample. Photographic evidence was obtained through the arthroscope in most cases with the Stortz Endocamera on $35 \mathrm{~mm}$ film with a synchronised light source.

Biopsy sections were immediately fixed in formalin or in a special fixative if the tissue was to be examined for immunofluorescence. ${ }^{8}$

Bone and joint scans were performed in 5 of the 19 patients. Material used was ${ }^{99 \mathrm{~m}}$ technetium methylene diphosphonate and a dose of $15 \mathrm{mCi}$ given by injection and checked on $x$-ray 3 hours later.
Four patients (cases 15, 17, 18, 19) have had synovial membrane examined for immunofluorescence. The biopsies were fixed according to the method of Michel et al.,${ }^{8}$ packed in coolant during air transport, and examined at the Department of Immunology, Royal Perth Hospital within 24 hours.

\section{Results}

Arthroscopic findings. Seventeen of the 19 patients arthroscoped were regarded as having synovitis. Arthroscopic findings included a low-grade erythema and oedema of the synovium; synovitis with fibrin strands seen through the instrument (Fig. 1); and frank synovitis with erythema and villus formation (Fig. 2). Ten shoulders were arthroscoped for investigation of nonspecific shoulder pain, and these were 


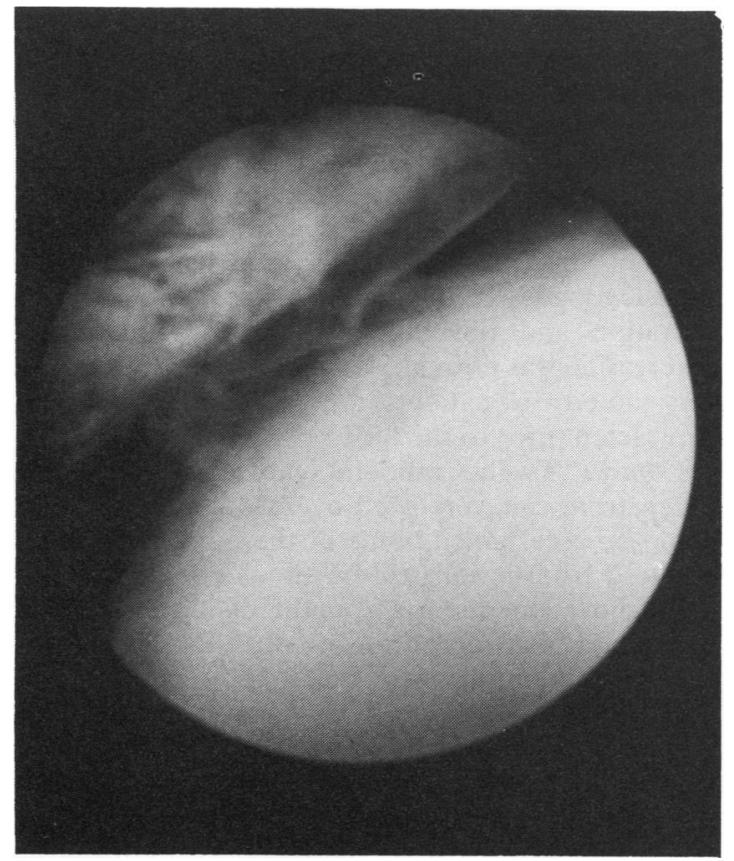

Fig. 1 Synovial erythema and fibrin on articular surfaces of shoulder joint. (Stortz Endocamera, $35 \mathrm{~mm}$ ).

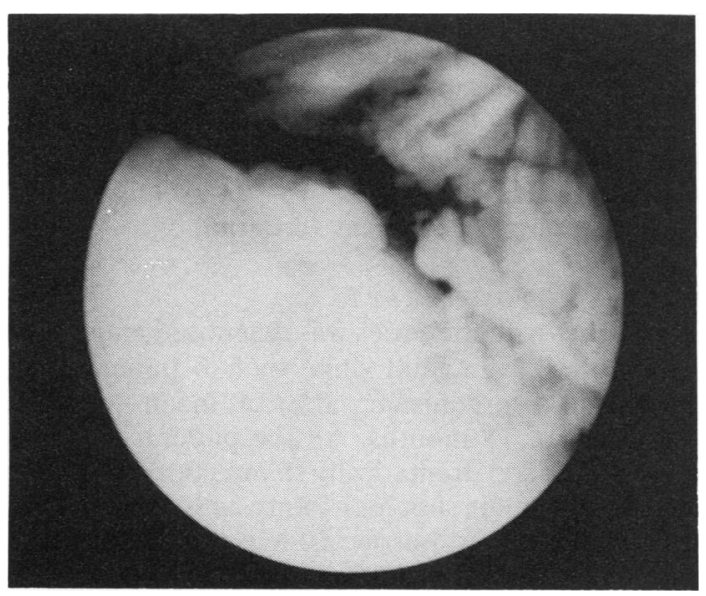

Fig. 2 Hypertrophic oedematous synovial membrane in a shoulder joint. (Strotz Endocamera, $35 \mathrm{~mm}$ ).

used as controls. No evidence of synovitis was seen in these cases. The joint surface of the shoulder was normal in the majority of cases, though several patients showed minor cartilage defects due to the degeneration of age.
Joint fluid. Four of the patients had joint effusions (one with a negative biopsy). The fluid in the shoulder joint was under pressure and flowed out through the instrument. Two patients had the joint fluid examined, and each showed a preponderance of mononuclear cells in the joint fluid.

Case 1 had a total white cell count of $2 \times 10^{\%} / 1$, with $80 \%$ mononuclear cells, and case 2 a total white cell count of $2.6 \times 10^{9} / 1$, with $72 \%$ mononuclears. Material for viral culture from the first case was sent to the State Health Department, Queensland, but was negative. No crystals were seen and the mucin clot was normal.

Histological findings. The histological changes on the whole were unimpressive when compared with

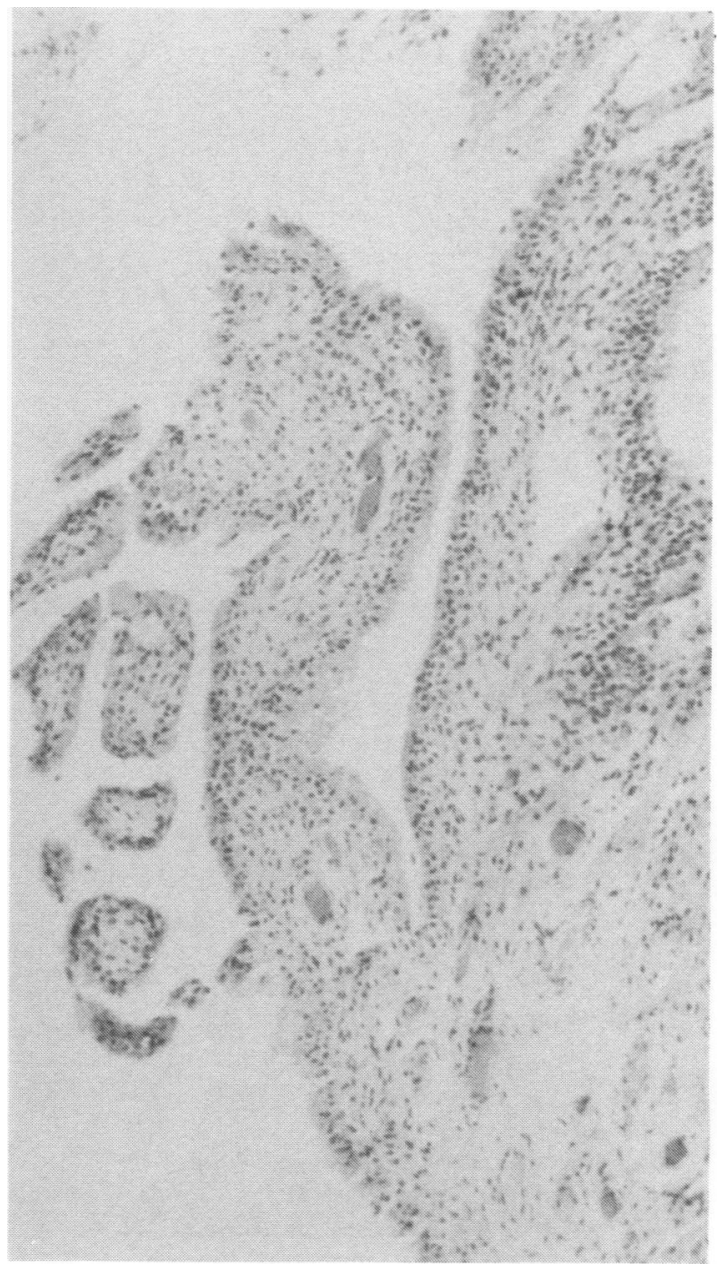

Fig. 3 Synovial biopsy from shoulder showing vascular engorgement and synovial cell hyperplasia. (Haematoxylin and eosin, $\times 65$ ). 
the florid picture frequently seen through the arthroscope (Figs 3 and 4). The sections were carefully examined simultaneously by a pathologist $\mathrm{Dr}$ R. L. Quinn and a clinician (W.A.C.D.).

HISTOLOGICAL CHARACTERISTICS

Vascular dilatation, engorgement, and perivascular oedema were present in all biopsies. Round cell

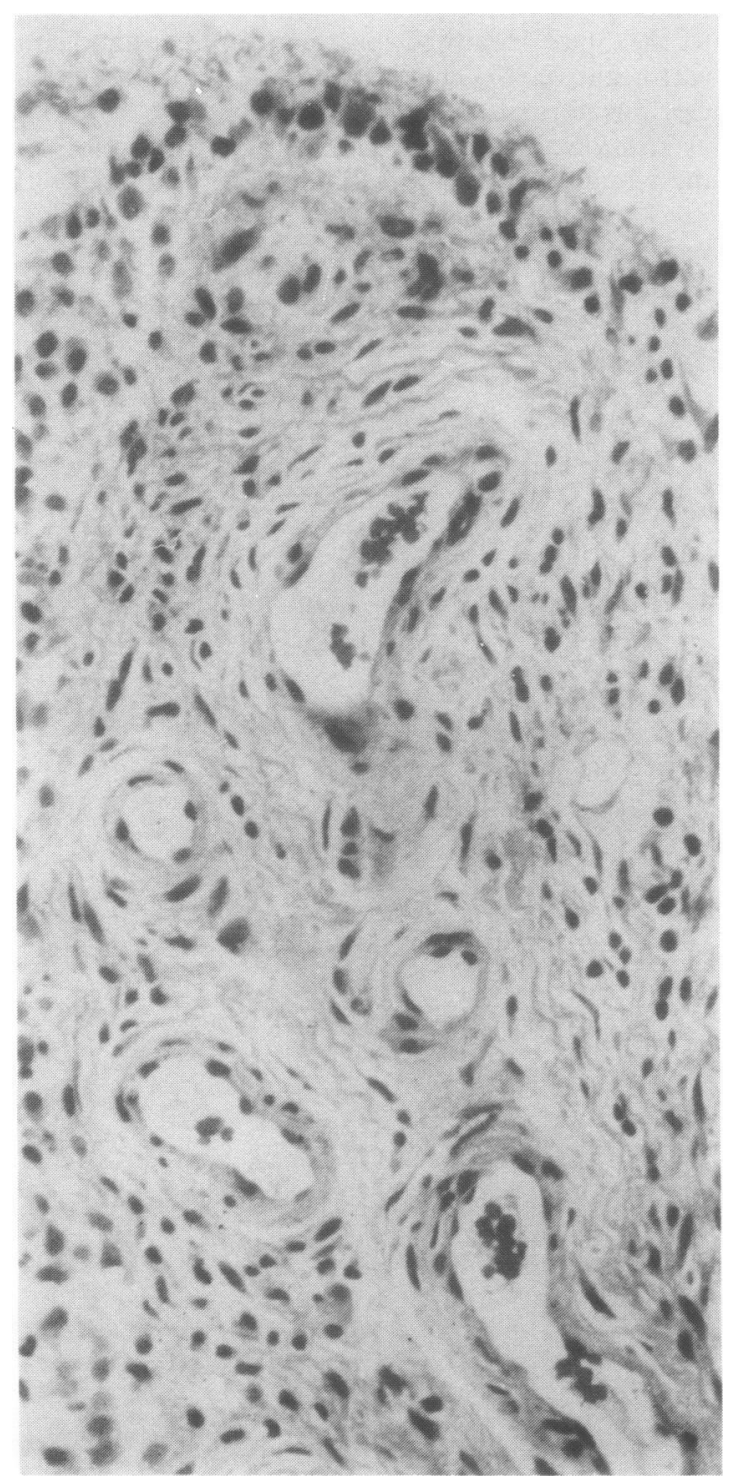

Fig. 4 Synovial biopsy from shoulder showing tip of a synovial villus with synovial cell proliferation interstitial oedema and vascular dilatation. Note absence of polymorphs. (Haematoxylin and eosin, $\times 400$ ). infiltration by lymphocytes was usual and perivascular infiltration common. One case showed extreme perivascular infiltration. Polymorphonuclear cells were a rarity in the sections. Variable proliferation of surface epithelium, with no irregular nuclei, suggesting a low-grade synovitis was seen. The changes were unlike those of rheumatoid synovitis. No surface fibrin deposition was noted. Only one artery in all the biopsies suggested a vasculitis with endothelial proliferation and fibrin deposition. Skeletal muscle where seen was normal. An increase in fibrous tissue was noted in patients whose illness had been protracted prior to the biopsy.

Control. Twelve random synovial samples were taken from cadavers aged over 55 years. So far as could be ascertained, none of these individuals had suffered from lesions of the shoulder joints in life. The synovial membrane from the shoulders of the 12 controls was normal, showing none of the features described in this article.

Bone and joint scans. The results of the 5 joint scans performed were disappointing. Only 2 patients showed positive uptake. One patient (case 10) had an increased uptake in the shoulder joints. His illness had been going for some months prior to diagnosis. The other patient (case 11) had an increase in her sternoclavicular joints despite an active synovitis of the shoulders noted at arthroscopy.

Immunofluorescent studies. Four patients (cases $15,17,18$, and 19) have had the synovial membrane examined for immunofluorescence. Of the 4 samples 3 showed fibrin deposition on endothelial cells; 2 had focal IgM and 2 C3 deposition. The IgM was intense and interstitial in case 15 and focal, possibly related to intravascular fibrinogen, in case 19 . One case (17) had no immunofluorescent abnormality.

RESPONSE TO THERAPY

The first case in the series was diagnosed and treated in October 1978, and since then 6 patients have ceased oral prednisone after a mean length of treatment of 18 months. All the patients described here responded dramatically to injections of corticosteroid into their shoulder joints, and all responded quickly to oral prednisone $10 \mathrm{mg}$ per day except for case 19 , who required $15 \mathrm{mg}$ per day to control the process. One patient, case 9 , declined to have oral corticosteroids and responded quite well to naproxen.

\section{Discussion}

We briefly reported our initial findings on arthroscopy of the shoulders in 6 patients with polymyalgia rheumatica in $1980 . .^{9}$ In the present study it can be 0 seen that, of the 19 cases, 7 were able to give up 
prednisone at the time of writing and none of the 19 had developed peripheral arthropathy, cranial arteritis, or other form of rhe umatic disease, confirming that polymyalgia rheumatica was the primary illness.

We suspect that polymyalgia rheumatica is a specific entity despite the difficulty in definition and that one is dealing with a spectrum of disease of similar aetiology. One of us (W.A.C.D.) in a private series of 40 cases recorded complete remission and the ability to withdraw oral steroids at times ranging from 3 months to 4 years. A small percentage of patients continue to need a small maintenance dose of prednisone over many years to control inflammation.

In this personal series of 40 patients only 3 developed clinical cranial arteritis. This low incidence of vascular complications is in keeping with other rheumatological studies. Subclinical cranial arteritis has been demonstrated pathologically by Bruk $^{6}$ in a higher than suspected percentage of cases. In our experience polymyalgia rheumatica usually runs a benign course, but it is necessary to watch for clinical and laboratory signs of inflammation.

It should be noted that those patients whose disease remained undiagnosed for some months tended to develop fibrosis of the subsynovial tissues. This would be in keeping with the clinical progression of shoulder stiffness and immobility.

As ${ }^{99 m}$ technetium diphosphonate is concentrated in the subchondral bone and joint fluid, it would follow that the low incidence of positive scans may be due to the fact that subchondral bone changes are minimal in polymyalgia rheumatica in comparison with the juxta-articular osteoporosis of rheumatoid arthritis. Similarly the turnover of joint fluid in polymyalgia rheumatica must be low in comparison with the active effusion in rheumatoid disease. These results are at variance with those reported by O'Duffy et al. ${ }^{7}$ Presumably this difference may be due to the different radioactive material used by O'Duffy, which was technetium pertechnetate.

It is of interest that Hollander's Textbook of Rheumatology ${ }^{10}$ published in 1960 makes no mention of polymyalgia rheumatica, while in the 1978 edition of Copeman's Textbook of the Rheumatic Diseases ${ }^{2}$ Dixon classifies polymyalgia with the soft tissue rheumatisms and states that 'the condition is identical with the prodromal phase of temporal arteritis.' In our opinion the relationship between temporal arteritis or giant cell arteritis and polymyalgia rheumatica is by no means clear, and to label them at the present state of our knowledge together is to cloud the issues of aetiology, pathology, and therapy. Various clinics-neurological, ophthalmological, and rheumatological-all report greatly differing percentages of complicating arteritis in polymyalgia rheumatica.

Coombes and Sharp ${ }^{11}$ considered the term to be a misnomer, diverting attention to the muscles. They were able to produce proximal limb pain by injecting the manubriosternal and sternoclavicular joints and interspinous ligaments with normal saline. They speculated that the proximal pain in polymyalgia rheumatica was referred from inflamed small central joints. In a personal communication (1980) Dr J. Sharp says his view is essentially unchanged.

One of the authors (W.A.C.D.) repeatedly observed immediate relief of pain and partial relief of stiffness following intra-articular injections of $2 \%$ lignocaine into the shoulder joints. This relief generally lasts 3-4 hours and is reproducible. These findings suggest that the arthritis of the shoulder joints in polymyalgia rheumatica is an important contributing factor to symptomatology.

If arthritis of the shoulder, hips, and small joints of the neck and shoulder girdle is not largely responsible for proximal pain in polymyalgia rheumatica, what are the alternatives? Muscle biopsies ${ }^{12}$ and electromyographic studies ${ }^{13}$ have all proved to be essentially normal, thus excluding myositis and fasciitis of muscle as causing the disease.

In this series of 19 cases the appearance of synovitis was seen through the arthroscope in 17 and shoulder joint effusions were noted in 4 , while one of the patients developed inflammation of sternoclavicular joints. Tenderness of the cervical spine was common. None of the 19 have yet developed temporal arteritis.

One must question why a low-grade synovitis in most patients produced such severe pain and stiffness. A systemic component of variable severity is usually present as shown by a raised ESR and other systemic symptoms such as the common complaint of a 'flu-like' illness at the onset and weight loss. Older people respond adversely to any injury to their shoulder joints, as shown by the frequency of adhesive capsulitis following minor trauma to the upper limb in this age group, who frequently have some degree of pre-existing osteoarthrosis. It is possible that a systemic illness, when combined with the predilection of the shoulders and neck to stiffen with low-grade inflammation, explains the severity of symptoms in contrast to the low-grade histological appearances of their synovial membrane.

Our experience with radioactive joint scans did not appear to help in the diagnosis of polymyalgia rheumatica when one compares the positive results noted in rheumatoid joints. Presumably the poor correlation between arthroscopically observed synovitis even with effusions and a rarely positive scan reflects the less aggressive nature of the joint inflammation. 
As mentioned earlier, the findings were at a variance with those of O'Duffy et al. ${ }^{7}$ and could have been due to the different radioisotopes used.

Temporal artery biopsies were not performed in any of our 19 patients, as further invasive procedures were not considered warranted. This matter has been thoroughly examined by Bruk. ${ }^{6}$ The 2 patients who had normal arthroscopic appearances despite clinical signs of arthritis of the shoulders were most interesting. One had a joint effusion, the other (patient no. 6) had a perfectly normal shoulder joint arthroscopically and histologically. It may be that a good deal of her pain was arising from her cervical spine or the small joints round the shoulder girdle.

The immunofluorescent studies are to be further pursued. The data so far are insufficient to gauge the importance of the immunofluorescence reported in our 3 patients. We note the reports of increased circulatory immune complexes found in sera by Park and his associates. ${ }^{14}{ }^{15}$ Perhaps there is a pathological spectrum in polymyalgia rheumatica varying from synovitis to arteritis with similar aetiological factors operating. In conjunction with the Department of Immunology, Royal Perth Hospital, we intend to pursue the immunological facets of this relatively common and perplexing illness.

We acknowledge the generous assistance of Dr R. L. Quinn, senior pathologist at the Princess Alexandra Hospital, and Dr K. Siddel, director of radiology, Princess Alexandra Hospital. We are most grateful to Professor B. Vernon-Roberts for his critical appraisal of the sections, and also to Professor G. Nuki and Dr S. Malawista, both of whom examined the slides and discussed the significance of the findings outlined in this paper.

The immunofluorescent sections were examined under the direction of Mr B. Houliston, Department of Immunology, Royal Perth Hospital.

\section{References}

1 Barber H S. Myalgia syndrome with constitutional effects: polymyalgia rheumatica. Ann Rheum Dis 1957; 16: 230-7.

2 Dixon A St J. Polymyalgia rheumatica and temporal arteritis. In: Scott J T, ed. Copeman's textbook' of the rheumatic diseases. Edinburgh: Churchill Livingstone, 1978: 953-8.

3 Bird H A, Esselinck W, Dixon A S T, Mowat A G, Wood P H N. An evaluation of criteria for polymyalgia rheumatica. Ann Rheum Dis 1979; 38: 434-9.

4 Gordon I, Rennie A M, Branwood A W. Polymyalgia rheumatica: biopsy studies. Ann Rheum Dis 1964; 23: 447-55.

5 Henderson D R F, Tribe C R, Dixon A St J. Synovitis in polymyalgia rheumatica. Rheumatol Rehabil 1975; 14: 244-50.

6 Bruk M I. Articular and vascular manifestations of polymyalgia rheumatica. Ann Rheum Dis 1967; 26: 103-16.

7 O'Duffy J D, Wahner $\mathrm{H} \mathrm{W}$, Hunder G G. Joint imaging in polymyalgia rheumatica. Mayo Clin Proc 1976; 51: 519-24.

8 Michel B, Milner Y, David K. Preservation of tissue fixed immunoglobulin in skin biopsies of patients with lupus erythematosus and bullous disease-preliminary report. $J$ Invest Dermatol 1973; 59; 449-52.

9 Douglas W A C, Martin B A, Morris J H. Polymyalgia rheumatica-an arthritis or arteritis? Med J Aust 1980; ii: 452-3.

10 Hollander J L. ed. Arthritis and allied conditions A textbook of rheumatology. 6th ed. Philadelphia: Lea and Febiger, 1960.

11 Coombes E N, Sharp J. Polymyalgia rheumatica. Lancet 1961; ii: $1328-31$.

12 Andrews F M. Polymyalgia rheumatica: a biopsy and follow-up study. Ann Rheum Dis 1965; 24: 432-8.

13 Chalmers T M, Alexander W R M, Duthie J J R. Polymyalgia: problems of differential diagnosis. Ann Rheum Dis 1964; 23: 123-30.

14 Park J R, Hazelman B L. Immunological and histological study of temporal arteries. Ann Rheum Dis 1978; 37: 238-43.

15 Park J R, Jones J G, Harkiss G D, Hazelman B L. Circulating immune complexes in polymyalgia rheumatica and giant cell arteritis. Ann Rheum Dis 1981; 40: 360-5. 